\title{
Online information related to childhood cancer and COVID-19 pandemic: a thematic analysis
}

\author{
Informações online relacionadas ao câncer infantil e pandemia da COVID-19: uma análise temática \\ Informaciones en línea relacionadas con el cáncer infantil y la pandemia de la COVID-19: un análisis temático
}

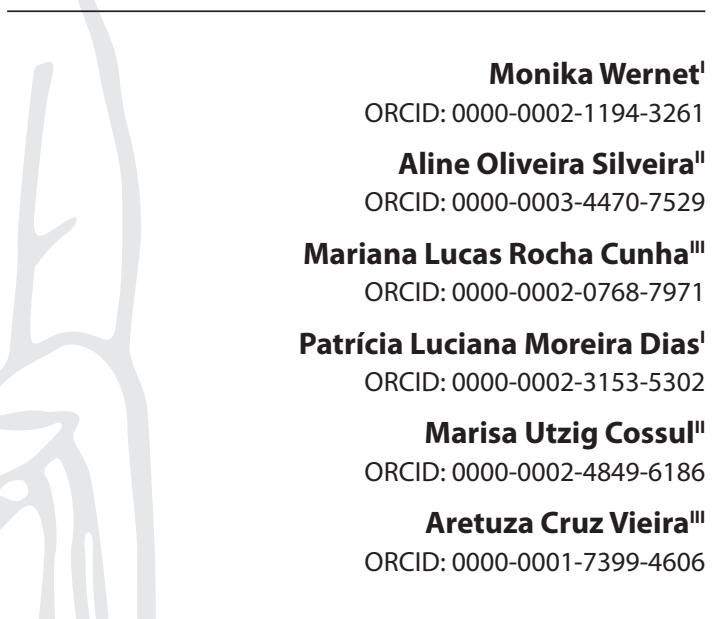

'Universidade Federal de São Carlos. São Carlos, São Paulo, Brazil.

"Universidade de Brasília. Brasília, Distrito Federal, Brazil. "'Hospital Israelita Albert Einstein. São Paulo, São Paulo, Brazil.

How to cite this article: Wernet M, Silveira AO, Cunha MLR, Dias PLM, Cossul UM, Vieira AC. Online information related to childhood cancer and COVID-19 pandemic: a thematic analysis. Rev Bras Enferm. 2021;74(Suppl 1):e20201056. doi: http://dx.doi.org/10.1590/0034-7167-2020-1056

Corresponding author: Monika Wernet E-mail:monika.wernet@gmail.com

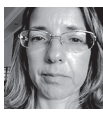

EDITOR IN CHIEF: Dulce Barbosa ASSOCIATE EDITOR: Priscilla Broca

Submission: $11-09-2020$

Approval: $16-12-2020$

\section{ABSTRACT}

Objective: To analyze online information available on the internet about COVID-19 and childhood cancer and discuss its reach potential with regard to supporting family functioning. Method: Documentary research supported by thematic analysis and the concept of family functioning and support. A total of 27 publications available on the websites of reference institutions in pediatric oncology, from March 1 to May 31, 2020, were analyzed. Results: Two themes guided the presentation of results with emphasis on language and sustainability assumptions to content, and to conveyed meanings and intentionality. The publications prospect families/people with basic knowledge about COVID-19 and have little information specific to the relationship with childhood cancer. Final considerations: Threatening circumstances require informational support. This study revealed incipient of specificity and a prescriptive tone in the online information available in early times of the pandemic questioning the scope of support for family functioning.

Descriptors: Access to Information; COVID-19; Cancer; Family; Pandemics.

\section{RESUMO}

Objetivo: Analisar informações online disponibilizadas na internet acerca da COVID-19 e câncer infantil e discutir seu potencial alcance em termos de suporte ao funcionamento familiar. Método: pesquisa documental apoiada na análise temática e nos conceitos de funcionamento e suporte familiar. Foram analisadas 27 publicações disponíveis em sites de instituições de referência em oncologia pediátrica, no período de 01 de março a 31 de maio de 2020. Resultados: Dois temas direcionam a apresentação dos resultados com destaque à linguagem e pressupostos de sustentabilidade ao conteúdo, e aos sentidos e intencionalidades veiculados. As publicações prospectaram famílias/pessoas lacunares de conhecimentos elementares acerca da COVID-19 e portaram poucas informações específicas à relação com o câncer infantil. Considerações finais: Circunstâncias ameaçadoras requerem suporte informacional, mas este estudo revelou incipiências de especificidade e um tom prescritivo nas informações online disponíveis em tempos iniciais da pandemia, questionando os alcances de suporte ao funcionamento familiar.

Descritores: Acesso à Informação; COVID-19; Câncer; Família; Pandemia.

\section{RESUMEN}

Objetivo: Analizar informaciones en línea disponibles en Internet sobre la COVID-19 y el cáncer infantil y discutir su alcance potencial en términos de apoyo al funcionamiento familiar. Método: Investigación documental, sustentada en el análisis temático y los conceptos de funcionamiento y apoyo familiar. Se analizaron 27 publicaciones disponibles en los sitios web de instituciones de referencia en oncología pediátrica, del 1 de marzo al 31 de mayo de 2020. Resultados: Dos temas orientan la presentación de los resultados, con énfasis en el lenguaje y los supuestos de sustentabilidad del contenido, y a los significados e intenciones transmitidos. Las publicaciones prospectan a familias/personas con conocimientos básicos sobre la COVID-19 y tienen pocas informaciones específicas sobre la relación con el cáncer infantil. Consideraciones finales: Circunstancias amenazantes requieren apoyo informativo. Este estudio reveló insipiencias de especificidad y un tono prescriptivo en las informaciones en línea disponibles en los primeros días de la pandemia, cuestionando el alcance del apoyo al funcionamiento familiar.

Descriptores: Acceso a la Información; COVID-19; Cáncer; Familia; Pandemias. 


\section{INTRODUCTION}

Informational support for the family of children with cancer is essential, it integrates their coping process, as well as eases stress, uncertainties and insecurities ${ }^{(1)}$. The internet is a resource for this ${ }^{(1-}$ 3), families of children with cancer would like to receive from the physicians indicative websites for informational consultations ${ }^{(1)}$. However, sometimes the quality of the information found on the internet is a concern for parents and professionals, promoting fear in using $\mathrm{it}^{(1-2)}$. Despite this, it is used with an emphasis on readiness to obtain information ${ }^{(2)}$.

The trajectory of the disease and the treatment of childhood cancer require families to make decisions. Thus, information is needed $^{(4)}$ and they usually lead the families in their more intense search in times of diagnosis and/or in the introduction of therapies $^{(3)}$. Misinformation and/or information overload do not usually contribute to family functioning ${ }^{(4)}$. However, every everyday situation experienced as a crisis, as is the case with pandemics, requires information. The alignment between access to information and the moment it is claimed is directly related to feelings of control and security in contrast to anxiety and a sense of $\operatorname{chaos}^{(5)}$.

Regarding the declaration of the COVID-19 pandemic, families of children who experience the oncological disease or its recovery faced the following question: "How are childhood cancer and COVID-19 related?". COVID-19 is a viral disease caused by the SARS-CoV-2 virus, which spreads mainly through respiratory droplets from infected people and close contacts ${ }^{(6)}$. Until the beginning of June 2020, no specific and dense articles on infection in children with cancer were published ${ }^{(6)}$. The pandemic confronts the experience of childhood cancer and determines, among other needs, informational ones.

The Institute of Patient and Family Centered Care highlights that the words adopted and the content of the communications that involve COVID-19 must be intended to strengthen the role of families as important partners for the care and safety of their members ${ }^{(7)}$. The information shared and sensitive to the uniqueness of each situation is a prerequisite of the philosophy of care centered on the child and the family $(C C C F)^{(7)}$. Supported by the CCCF's prerogative, the concept of family functioning is important and refers to the family's skills in dealing with stressful events, portraying the way its members behave towards each other, both in daily activities and in aspects related to communication, roles, problem solving and beliefs ${ }^{(8)}$. It is known that families access information on the internet, which have potential consequences for family coping. Discussions about this information on the internet and its impact on the family are relevant to health care in the direction of promoting family health.

Based on the above, this study asked: "What information was available to families of children with cancer on the internet, in the early days of the COVID-19 pandemic? How did this information relate to family functioning?".

\section{OBJECTIVE}

To analyze online information available on the internet about COVID-19 and childhood cancer and discuss its reach potential with regard to supporting family functioning.

\section{METHODS}

\section{Ethical aspects}

This is a documentary study, which focuses on the search for information in documents that have not received analytical treatment in critical reconstruction and new inferences and conclusions $^{(9)}$. In this case, publications on publicly accessible websites within the area of pediatric oncology.

\section{Theoretical-methodological framework}

The study adopted the systemic premise that diseases and life challenges impact the family unit and, conversely, family functioning, with influences on the health and well-being of each family member ${ }^{(8)}$. This is especially true in the current COVID-19 pandemic. Our assumption is that the disease and its prevention is a family matter, manifesting itself across the entire spectrum and scale of the current pandemic ${ }^{(10)}$ in which information is part of this panorama.

For the analysis of the data, Thematic Analysis (TA) was selected in the proposal by Clarke and Braun ${ }^{(11)}$, whose analytical process is developed from a constant and active recursive movement through the data, with readings and (re) readings of the empirical material. Familiarization is the initial movement, for which repeated readings are developed in the direction of immersion, attention to the meanings, ideas and patterns. From this movement, global perceptions and ideas for codes take shape and introduce the researcher in the next step, aimed at establishing initial codes, established from data characteristics assessed in the light of the phenomenon under exploration. The next analytical effort is aimed at taking the codes to identify 'initial' themes and their relationships with each other. Once the themes are established, they are refined in terms of the coherence of the whole and of what is central to it, and then report the results supported by them.

\section{Data source}

The identification of the websites for the location of the publications occurred from a brainstorming between the authors of this study, with the intention of replicating a process similar to the family movement in the search for information. A total of 12 possible sources of information were identified (10 Brazilian ones and 2 international ones). Then, maintaining efforts to develop something close to that carried out by families, a free and unsystematic search was performed on Google, using the words "cancer/cancer", "child/criança" and "COVID-19". This movement revealed 10 international websites and 3 Brazilian ones. Thus, in total, 12 international websites and 13 Brazilian ones were explored.

\section{Data analysis}

The following inclusion criteria for the selection of publications were adopted: (1) being directed to families of children with cancer; (2) addressing issues related to the COVID-19 pandemic; (3) having the date of publication between March and May 2020. The search period was defined as the search for information by families with children with cancer was concentrated in the first sixty 
days after the cancer diagnosis, declining after that ${ }^{(3)}$. Therefore, this study took publications dated between 03/11 to 05/11/2020.

The search process for publications on the websites was carried out from April 15 to May 15, 2020. A total of 25 publications were identified for analysis, of which 3 (three) were excluded because they did not meet the inclusion criteria. In addition, between May 13 and 14, 2020, an active search for other publications was carried out with the partners listed on the Brazilian websites listed in the study and which did not appear in the initial procedures for locating the analysis corpus. A further 14 publications were identified, of which 5 (five) met the criteria of this study. Altogether, 27 publications (Chart 1) were submitted to analysis.

It is noteworthy that the search and analysis process took place in a paired manner and the final corpus resulted from a consensus meeting between all authors of this study. The inductive interpretive processes allowed the establishment of themes, from which the findings were reported. The study followed the standards for qualitative research reports, specifically the recommendations of the Standards for Reporting Qualitative Research (SRQR) ${ }^{(12)}$.

\section{RESULTS}

The results are organized around two themes: 'Language and theoretical assumptions' and 'Informational content and family functioning'.

Chart 1 - Information about the corpus of analysis of the "Online information related to childhood cancer and the pandemic of COVID-19: a thematic analysis" study, Brazil, 2020

\begin{tabular}{|c|c|c|}
\hline Source & Title of publication & Country \\
\hline $\begin{array}{l}\text { AC Camargo Cancer Center } \\
\text { https://www.accamargo. } \\
\text { org.br }\end{array}$ & $\begin{array}{l}\text { The new coronavirus } \\
\text { and care for childhood } \\
\text { cancer }^{(13)}\end{array}$ & Brazil \\
\hline $\begin{array}{l}\text { American Childhood Cancer } \\
\text { Organization https://www. } \\
\text { acco.org }\end{array}$ & $\begin{array}{l}\text { Coronavirus guidance for } \\
\text { young cancer patients }{ }^{(14)}\end{array}$ & USA \\
\hline $\begin{array}{l}\text { American Society of Clinical } \\
\text { Oncology https://www. } \\
\text { ascopost.com }\end{array}$ & $\begin{array}{l}\text { COVID-19 and pediatric } \\
\text { patients with cancer }{ }^{(15)}\end{array}$ & USA \\
\hline $\begin{array}{l}\text { Brazilian Lymphoma and } \\
\text { Leukemia Association } \\
\text { https://www.abrale.org.br }\end{array}$ & $\begin{array}{l}\text { Protect yourself from } \\
\text { coronavirus and rumors } \\
\text { about it }{ }^{(16)}\end{array}$ & Brazil \\
\hline $\begin{array}{l}\text { Australian \& New Zealand } \\
\text { Children's Haematology/ } \\
\text { Oncology Group } \\
\text { https://anzchog.org }\end{array}$ & $\begin{array}{l}\text { COVID-19 Guidance and } \\
\text { FAQ for children and } \\
\text { young people undergoing } \\
\text { cancer treatment }^{(17)}\end{array}$ & $\begin{array}{l}\text { Australia } \\
\text { and New } \\
\text { Zealand }\end{array}$ \\
\hline $\begin{array}{l}\text { BC Children's Hospital http:// } \\
\text { www.bcchildrens.ca }\end{array}$ & $\begin{array}{l}\text { COVID-19 and children - } \\
\text { information for patients }^{(18)}\end{array}$ & Canada \\
\hline $\begin{array}{l}\text { Boldrini Center } \\
\text { www.boldrini.org.br }\end{array}$ & $\begin{array}{l}\text { General Covid-19 } \\
\text { Guidelines }{ }^{(19)}\end{array}$ & Brazil \\
\hline $\begin{array}{l}\text { Childhood Cancer } \\
\text { Association https:// } \\
\text { childhoodcancer.asn.au }\end{array}$ & $\begin{array}{l}\text { Our response to COVID-19 } \\
\text { (coronavirus) }^{(20)}\end{array}$ & Australia \\
\hline $\begin{array}{l}\text { Chidren with cancer } \\
\text { UK https://www. } \\
\text { childrenwithcancer.org.uk }\end{array}$ & $\begin{array}{l}\text { Give hope to children facing } \\
\text { cancer amid COVID-19 } \\
\text { uncertainty / Looking within } \\
\text { during the COVID-19 } \text { crisis }^{(21)}\end{array}$ & $\begin{array}{l}\text { United } \\
\text { Kingdom }\end{array}$ \\
\hline $\begin{array}{l}\text { Children's Cancer and } \\
\text { Leukaemia Group } \\
\text { https://www.cclg.org.uk }\end{array}$ & $\begin{array}{l}\text { COVID-19 guidance } \\
\text { for children and young } \\
\text { people with cancer } \\
\text { undergoing treatment }\end{array}$ & $\begin{array}{l}\text { United } \\
\text { Kingdom } \\
\text { and } \\
\text { Ireland }\end{array}$ \\
\hline
\end{tabular}

Chart 1 (concluded)

\begin{tabular}{|c|c|c|}
\hline Source & Title of publication & Country \\
\hline $\begin{array}{l}\text { Children's Oncology } \\
\text { Group http://www. } \\
\text { survivorshipguidelines.org }\end{array}$ & $\begin{array}{l}\text { COVID-19 and Cancer } \\
\text { Survivors: What Do I Need } \\
\text { to Know? }{ }^{(23)}\end{array}$ & USA \\
\hline $\begin{array}{l}\text { Cure Childhood } \\
\text { cancer https:// } \\
\text { curechildhoodcancer.org }\end{array}$ & $\begin{array}{l}\text { CURE childhood cancer } \\
\text { and COVID-19(24) }\end{array}$ & USA \\
\hline $\begin{array}{l}\text { GACC Bahia - Support group } \\
\text { for children with cancer } \\
\text { http://www.gaccbahia.org.br }\end{array}$ & $\begin{array}{l}\text { Learn about the measures } \\
\text { adopted by GACC-BA to } \\
\text { cope with Covid-19(25) }\end{array}$ & Brazil \\
\hline $\begin{array}{l}\text { GPACi - Childhood Cancer } \\
\text { Research and Assistance } \\
\text { Group https://www.gpaci. } \\
\text { org.br }\end{array}$ & $\begin{array}{l}\text { What is coronavirus? Know } \\
\text { when it was discovered } \\
\text { and what preventive } \\
\text { measures to take }\end{array}$ & Brazil \\
\hline $\begin{array}{l}\text { GRAACC - Support Group } \\
\text { for Adolescents and } \\
\text { Children with Cancer } \\
\text { https://graacc.org.br }\end{array}$ & $\begin{array}{l}\text { GRAACC Covid-19 } \\
\text { Report }^{(27)}\end{array}$ & Brazil \\
\hline $\begin{array}{l}\text { Erasto Gaertner Hospital } \\
\text { https://erastogaertner.com.br }\end{array}$ & Coronavirus coping plan ${ }^{(28)}$ & Brazil \\
\hline $\begin{array}{l}\text { Children's Oncology } \\
\text { Hospital Belem https:// } \\
\text { oncologicoinfantil.org.br }\end{array}$ & $\begin{array}{l}\text { Children who are part } \\
\text { of the coronavirus risk } \\
\text { group }^{(29)}\end{array}$ & Brazil \\
\hline $\begin{array}{l}\text { National Cancer Institute } \\
\text { https://www.inca.gov.br }\end{array}$ & $\begin{array}{l}\text { INCA against coronavirus / } \\
\text { Frequently asked questions: } \\
\text { cancer and coronavirus }^{(30)}\end{array}$ & Brazil \\
\hline $\begin{array}{l}\text { Oncoguia Institute http:// } \\
\text { www.oncoguia.org.br }\end{array}$ & Coronavirus ${ }^{(31)}$ & Brazil \\
\hline $\begin{array}{l}\text { Ronald McDonald Institute } \\
\text { https://institutoronald.org.br }\end{array}$ & $\begin{array}{l}\text { COVID-19. We need you! } \\
\text { Make a special donation }^{(32)}\end{array}$ & Brazil \\
\hline $\begin{array}{l}\text { ITACI - Childhood Cancer } \\
\text { Treatment Institute } \\
\text { https://www.itaci.org.br }\end{array}$ & $\begin{array}{l}\text { Special service: } \\
\text { COVID-19(33) }\end{array}$ & Brazil \\
\hline $\begin{array}{l}\text { Brazilian Society of Pediatric } \\
\text { Nurses } \\
\text { https://sobep.org.br }\end{array}$ & $\begin{array}{l}\text { Recommendations of } \\
\text { the Brazilian Society of } \\
\text { Pediatric Nurses in times of } \\
\text { Coronavirus (COVID-19) }\end{array}$ & Brazil \\
\hline $\begin{array}{l}\text { Brazilian Society of Pediatric } \\
\text { Oncology } \\
\text { http://sobope.org.br }\end{array}$ & $\begin{array}{l}\text { Important announcement } \\
\text { about COVID-19(35) }\end{array}$ & Brazil \\
\hline $\begin{array}{l}\text { Brazilian Society of Pediatrics } \\
\text { https://www.sbp.com.br }\end{array}$ & $\begin{array}{l}\text { Children and adolescents } \\
\text { with cancer: Special care in } \\
\text { times of coronavirus }{ }^{(36)}\end{array}$ & Brazil \\
\hline $\begin{array}{l}\text { St Jude Chidren's Research } \\
\text { Hospital } \\
\text { https://together.stjude.org }\end{array}$ & $\begin{array}{l}\text { What does COVID-19 } \\
\text { (Coronavirus) mean for } \\
\text { children with cancer or } \\
\text { other illnesses? }\end{array}$ & USA \\
\hline $\begin{array}{l}\text { World Child Cancer } \\
\text { https://www. } \\
\text { worldchildcancer.org }\end{array}$ & $\begin{array}{l}\text { Responding to } \\
\text { coronavirus/COVID-19(38) }\end{array}$ & $\begin{array}{l}\text { United } \\
\text { Kingdom }\end{array}$ \\
\hline $\begin{array}{l}\text { Young Lives vs Cancer } \\
\text { https://www.clicsargent. } \\
\text { org.uk }\end{array}$ & $\begin{array}{l}\text { Coronavirus guidance for } \\
\text { young cancer patients }{ }^{(39)}\end{array}$ & $\begin{array}{l}\text { England } \\
\text { / Wales / } \\
\text { Scotland }\end{array}$ \\
\hline
\end{tabular}

\section{Theme 1: Language and Theoretical Assumptions}

The publications were presented in textual format and used in the information direction, highlighting issues related to the COVID-19 disease and its potential consequences in the experience of childhood cancer. Denotative language prevailed and was accessible, direct, clear and objective, with the potential for assimilation and apprehension by parents/family members. 
The predominance was of descriptive and/or explanatory publications, with the intention of providing knowledge about the epidemiological behavior of the disease, containment, prevention and treatment, as well as actions to guarantee well-being, social and economic support to families, with reference to the political, economic and geographical space.

Some publications have used singular first-person questions and answers as strategies, such as "what should I do if my child is in the vulnerable group?", "How can coronavirus affect my child who is undergoing cancer treatment?". In addition, on a few websites, we identified a space for parents to publish reports, share their experiences, knowledge and doubts. The publications in this scope adopted simple language, characterized by words and text structures that favored a context of empathy, conversation and sharing of experiences. In addition, they were less imposing and more assertive, considering the assessment that parents/ family members make of their living conditions and possibilities for reorganization required at the time of the pandemic. However, in the set of publications, the predominance was of an argumentative-persuasive tone, with prescription of attitudes and behaviors, in addition to an emotional appeal. The language combined simpler terms and explanations with more technical expressions. It should also be noted that a few publications had an appeal for solidarity, and the information related to COVID-19 was intended to raise awareness and mobilize civil society for donations for institutions to act by coping with the coronavirus.

The contents made available to families are based on technical and scientific references, mostly produced by institutes, and collaborating centers for evidence-based practice (such as The National Institute for Health and Care Excellence - NICE), societies (such as American Cancer Society), World Health Organization (WHO) guidelines, country specific government protocols, norms, guidelines and public health policies and scientific articles. However, in many publications, the sources of theoretical support for knowledge were not declared or were referenced to the person of a professional, an aspect that is very present in those linked to health care institutions for children with cancer.

\section{Theme 2: Informational Content and Family Function Support}

Publications can be divided into two main content follow-ups: general, focused exclusively on COVID-19; and specific, bringing the relationship COVID-19 and childhood cancer. The prevalence of the first follow-up was notable and expressive in publications on Brazilian websites. In both content follow-ups, proposals were made for family dynamics, with a view to protecting the child against infection by SARS-CoV-2, ensuring the maintenance of oncological monitoring and mitigating emotional developments.

The follow-up related to the general contents included publications on the following themes: characterization of the disease (what is COVID-19?), Transmissibility and high potential for contagion of the virus (how is COVID-19 transmitted?), Signs and symptoms, management and clinical treatment. Children were placed at a lower risk group for the development of the severe form of the disease, although they were its vectors. As for the limits, they point to a lack of studies that explore the effects of
SARS-CoV-2 in immunologically affected children and the lack of specific drug treatment or vaccine for the disease. Measures for the prevention and control of the disease were guided, especially in terms of avoiding close contact with people with the symptoms of COVID-19 and travelers, social self-isolation (staying at home) and social distance (avoiding crowds). Publications on international websites also dealt with the contextualization of the epidemiological behavior of the disease in the different geographical regions covered by the institutions, local government actions and the respective social restrictions imposed as a result of the epidemic. Thus, some addressed how these measures affect the care of children with cancer in specialized centers, with regard to the sustainability, continuity and quality of health services.

The publications were intended to sensitize the family to measures that prevent the occurrence of the infection, when almost all of them brought signs suggestive of the infection by the SARS-CoV-2 virus and the actions that minimize the contamination.

In institutions referring to children with cancer and their families, the care flowchart occupied the main pages and/or was easily accessible. In addition, information regarding the call center regarding suspected flu syndromes/suspected coronavirus infection was available on some websites, while on others there was a link for sending questions. In most of them, there was notification of restriction of care for patients already registered. A few websites brought the recommendation to, when suspected of infection, seek the children's physician.

It is worth noting that many publications emphasized that measures for the pandemic were well known to families that experience childhood cancer, with no news regarding recommendations for infection prevention. The publications covered the following subthemes: characterization of the vulnerability and risks of the child with cancer, especially those who are in the active phase of treatment, who have undergone bone marrow transplantation in the last 12 to 24 months and those with chronic conditions secondary to treatment or cancer; susceptibility of children with cancer to infection and the development of severe forms of COVID-19; contact restriction, isolation and shielding measures for the child; hygiene measures, respiratory etiquette and self-care; use of individual protective equipment by the child, family members and professionals who provide care; maintenance of cancer treatment and medical and nursing consultations considered essential; and support in the face of the family's socioeconomic and emotional needs, enhanced during the pandemic.

The idea that children with cancer are at risk or more susceptible to COVID-19 due to their immunological impairment permeated the information made available to families. For children classified as extremely vulnerable, from the oncological point of view, the strict social isolation and the additional restrictions or care in contacts in the domestic sphere, especially regarding siblings who attend school and parents who maintain a routine of work in essential services, were signaled. In some cases, the recommendations were that the healthy brother should not go to school to protect the child with cancer. The idea of high risk was associated with that of strict social isolation ("shielding"), which acquires relevance as a way to keep the child safe from COVID-19.

Topics such as intra-family relationships, socialization and school activities of children with cancer and healthy siblings, 
emotional needs, difficulties, feelings (concerns, afflictions and fears), uncertainties and coping with multiple difficult situations such as cancer and COVID-19 were addressed with less frequency in publications, especially in Brazil. Thus, the following themes were highlighted: interaction with the child, handling feelings and financial issues.

In the topic interaction with the child, the indications were to have a dialogue about the coronavirus. Thus, the exploration of repercussions on the child's daily life was highlighted, such as the absence/restrictions on school and extended family life, and the importance of sensitivity and recognition of the feelings exposed by the child was reinforced, as well as the adequacy of the conversation to its developmental moment and to what is presented as curiosities. The indications were for interactions that bet on a sensitive, supportive and dialogical attitude among family members. A few websites have provided playful and educational materials to mediate this dialogue.

In the set of discussions related to interaction with the child, the importance of establishing a routine, the use of strategies to maintain contact with classmates and family members, as well as the promotion of games and playful activities with a view to occupation, leisure and mental health of the child were guided. The importance of dialogue between parents and between them and the child was evidenced, especially on international websites, with an emphasis on exploring feelings, concerns and fears in a frank, honest and shared way, under the explanation that this promotes the apprehension of what they are going through, with possibilities of perceiving paths, coping strategies. Specifically, a website (https:// www.childrenwithcancer.org.uk) featured publications from parents sharing perceptions and management of the situation at COVID-19, with concrete action tips to minimize stress and parental distress.

Regarding the concerns and aspirations of parents, very few websites explain that the knowledge about COVID-19 is in full development and with great dynamism.

In non-governmental organizations, in which the social role of material and financial support is assumed as a mission, publications were identified that sought to present to the family what they can find of resources. Specifically, in those in which donations are a goal, giving visibility to the institution's action regarding efforts to maintain donations and services arising was a hallmark. The COVID-19 pandemic was mentioned as a time of "struggle" and of "joining forces", in which financial assistance by society is essential for the continuity and sustainability of care actions to families and children.

\section{DISCUSSION}

The informational support provided in the early days of the COVID-19 pandemic and accessible to the families of children with cancer focused on the risk and susceptibility of the child to acquire and develop severe forms of the disease, given their condition of immunosuppression. The predominance was of an argumentative-persuasive communication pattern, with prescription of attitudes and behaviors that prevent contamination, with strong emotional appeal. This can, instead of providing support, generate feelings of inadequacy, fear and guilt(4). Persuasion is a barrier to information effectiveness, which tends to be restricted in sensitivity to values, emotions, needs, life and care trajectories.
Excessive, contradictory and unspecific information does not contribute to the confidence and security of families ${ }^{(4)}$ who seek information in online environments.

The COVID-19 pandemic has changed the provision of care for children with cancer worldwide, and the dissemination of information and useful links is emerging, especially due to the rare reports about the impact of COVID-19 on children with cancer $^{(40)}$. It follows that obtaining information is essential to family functioning. The pandemic represents a global threat to safe and effective care for children with cancer and their families ${ }^{(41)}$. Thus, parents experience a high level of anxiety, fear and uncertainty, which requires professional understanding ${ }^{(41)}$ and frank and realistic interactional and informational strategies. The two greatest needs of families during an illness are information and support, which intersect ${ }^{(42)}$. Social media are resources for families to have their voices heard, sharing their stories among themselves and with health professionals ${ }^{(42)}$, something that is not often present in the publications analyzed here.

The CCF seeks to support family functioning through collaborative care ${ }^{(43)}$. Thus, we highlight that the landscape of cancer changes, as well as that of the pandemic of COVID-19, with impacts on the informational needs of the family. Thus, the prompt sharing of information is a central component ${ }^{(11,43)}$, with attention to the provision of timely and accurate information to support the reorganization of the family in the face of complex and challenging events, such as the experience and management of childhood cancer ${ }^{(43)}$ and pandemics. Adequate and appropriate information helps families to manage health problems, adopt healthy practices and adapt to challenges ${ }^{(42)}$, However, they are dependent on technical quality, an aspect that is sometimes questioned ${ }^{(1-2,44)}$. Few studies are aimed at evaluating this quality, a limit of this study as well. However, it was emphasized in our results that there are few publications that made it clear which scientific or professional evidence supported it. The low quality of information compromises the effect of informational support and can negatively affect family functioning, being a concern in the context of childhood cancer ${ }^{(2)}$. This data can be the focus of future explorations, such as "what is the trust that families place in information transmitted on the internet?".

On most sites, the attempt to allay concern about the potential risk of COVID-19 emerged on the grounds that these families were already sufficiently informed and used to protecting their children from infection. Despite the significant knowledge that these families acquire to protect their children, attitudes of minimization reinforce the feeling of loneliness and abandonment in the face of the pilgrimage in search of healing or preserving the child's life, in addition to not meeting the value of the human being and possibilities of family functioning ${ }^{(45)}$. The recognized role of parental protection assumed by these families is also noteworthy, as their child is perceived as vulnerable, even years after the completion of cancer therapy. It is known that families of survivors of the disease continue to search for information ${ }^{(46)}$.

Communication with families of children with cancer should provide for more than simply providing information, and it is relevant to have the aim of promoting support in line with values and needs $s^{(47)}$, which determines personalized communication ${ }^{(47)}$. Thus, websites need to consider more interactive channels with 
the family, allowing their placement, their voice. The attempt to engage in dialogue with the family was not present in most of the websites, with limits on the interaction channel. In addition, the structure of the website truncated navigation, since few were the ones that had a field for placing a search term. A North American study that examined the themes present in the exchanges established by parents of children with leukemia, through publicly available pages on Facebook, identified that documenting the cancer journey, sharing the emotional tension associated with care, promoting awareness and defense of the child with cancer, raising funds, mobilizing support and expressing gratitude for the support portray their needs ${ }^{(48)}$. The authors highlighted the importance of health professionals using digital platforms to share their experiences with families, considering them as important tools for communication, information and support ${ }^{(48)}$. In the context of family nursing, it is highlighted how much social media are tools to reach and connect families to social support. Social connections and practical support, aimed at concrete needs, are protective factors for families in times of crisis and need ${ }^{(42)}$.

Regarding the specific needs of the child, the developmental ones were covered in very few publications, being treated in a generic way. Playing was rarely addressed in publications. In the context of childhood cancer, there is a predominance of a utilitarian conception of playing, in the direction of therapeutic support, for the elaboration of situations faced by the child during the diagnosis and treatment ${ }^{(49)}$, an aspect similar to that present in the analyzed publications. The child as a person, with the essential need to play, was little thought. This gap can have repercussions on restrictions, since it is known that parents of children with cancer reveal concerns about the occurrence of accidents and injuries when playing, either due to the devices implanted in the child's body, or due to physical restriction and pain ${ }^{(49)}$. The publications could have offered more robust and specific contributions, given the fact that the family interacts with other media that discuss the impact of isolation on child development and recommend the provision of ludic activities and games, with a view to children's mental health and easing the distance from children peers in the face of disruption of school activities. Providing spaces for children to build themselves in action, being able to elaborate questions in the environment in which they are inserted, as well as having efforts to legitimize the way they see this process, looking and listening to children, were incipiently incorporated in the analyzed information.

Still considering the child as a person and their need to try to understand and act in the face of what the world reveals to them, this aspect was rarely addressed in publications, with a predominance of recommending parents to dialogue with their children. Sensitive listening to the issues that cause concern is an essential step to welcoming, which implies sensitivity to what is exposed by the child. The publications analyzed were restricted to the adopted language and the strategies that can mediate the informative conversation about COVID-19. In order to achieve effective communication, it is important to consider what the child understands about the disease and its causes.

Finally, we highlight the place occupied by Non-Governmental Organizations (NGOs), whose social role is undeniable in the context of pediatric oncology, especially with families that are economically and culturally disadvantaged. When these institutions are restricted to the message "we continue with efforts to raise donations", opportunities are lost to convey informative contributions that could be used by families to face the situation. NGOs are recognized as having a great influence on the behavior of citizens ${ }^{(50)}$ In this study, we identified a restricted use of information space to the detriment of donations.

\section{Limitation of the study}

The process of locating websites and consequent publications made use of the brainstorm and search with Google. However, the inclusion of the authors in the area of pediatrics and oncopediatrics minimizes the fragility of the corpus of data put under analysis. In addition, in the same direction, structuring this location, looking for ways that families would probably do it, unfolds in a set of information that has a close chance of being those that families would reach.

Another limitation is the period put to the analysis, although it portrays the real context of information made available to families in the early times of the pandemic, an excerpt from the study.

\section{Contributions to the area}

Thematizing online information made available to families in the context of health care is relevant and of critical contribution to rethink the ways and references that guide informational support on the internet. This is more pressing when taking websites that somehow assume such action in their identity and are linked to well-characterized illness experiences, as is the case of childhood cancer. It is urgent that online informational support in health takes references other than technical knowledge about the disease, seeking to incorporate discussions about the experiences of those who are seeking informational support.

Publishing online information in the context of health care represents an important support for people and families, but it lacks development from a broader perspective, overcoming a prescriptive posture and devoid of consideration of the experience of those who are involved in the subject matter, because otherwise, the limits of the support range are previously given.

\section{FINAL CONSIDERATIONS}

The study gave visibility to the publishers' conceptions regarding the interlocutor (families/people who experience childhood cancer) in the space-time range of the initial pandemic times. The interrelation between the predominant (persuasive) discourse and the thematic content (preventing the contamination of the child who is immunologically susceptible) suggests intentions of behavioral reach with information support. Thus, it is questioned about the reach that publications had with family functioning. Did they obstruct? Did they add anxiety?

The statements contained in the publications prospect families/ people with basic knowledge about COVID-19 and its containment. In addition, if every statement is a position in relation to the other, renewals are necessary in the area of informational support in pediatric oncology, especially regarding experience and family functioning. therefore, international publications are more aligned with the CCCF, with a dialogical stance and powerful 
references to health education practices. Threatening, dynamic and uncertain circumstances, such as childhood cancer and the pandemic by COVID-19, require continuous information support, in which the information conveyed online emerges while being widely accessed. Qualifying this aspect is urgent, so that it does not become a suffering and hinders family confrontations.

\section{FUNDING}

This study was financed in part by the Coordenação de Aperfeiçoamento de Pessoal de Nível Superior - Brasil (CAPES) - Finance Code 001 and in part by the Master Professional Program in Nursing, Hospital Israelita Albert Einstein.

\section{REFERENCES}

1. Domínguez M, Sapiña L. Pediatric cancer and the internet: exploring the gap in doctor-parents communication. J Cancer Educ. 2015;30(1):145-51. https://doi.org/10.1007/s13187-014-0700-4

2. Levine DR, Liederbach E, Johnson L, Kaye EC, Spraker-Perlman $\mathrm{H}$ et al. Are we meeting the informational needs of cancer patients and families? perception of physician communication in pediatric oncology. Cancer. 2019;125(9):1518-1526. https://doi.org/10.1002/cncr.31937

3. Phillips CA, Hunt A, Salvesen-Quinn M, Guerra J, Schapira MM, Bailey LC, et al. Health-related Google searches performed by parents of pediatric oncology patients. Pediatr Blood Cancer. 2019;66(8):e27795. https://doi.org/10.1002/pbc.27795

4. Robertson EG, Wakefield CE, Shawn J, Darligton AS, McGill BC, Cohn RJ, Fardell JE. Decision-making in childhood câncer: parent's and adolescent's viwes ad perceptions. Support Care Cancer. 2019;27:4331-40. https://doi.org/10.1007/s00520-019-04728-x

5. Mu P-F, Lee M-Y, Sheng C-C, Tung P-C, Huang L-Y, Chen Y-W. The experiences of family members in the year following the diagnosis of a child or adolescent with cancer: a qualitative systematic review. JBI Database System Rev Implement Rep. 2015;13(5):293-329. https://doi. org/10.11124/jbisrir-2015-1698

6. Ruggiero A, Romano A, Attinà G. Covid-19 and children with cancer: are they at increased risk of infection?. Pediatr Res. 2020[cited 2020 Apr 23]. https://doi.org/10.1038/s41390-020-0919-1

7. Institute for patient - and family - centered care [Internet]. PFCC and COVID-19 [cited 2020 Jul 12]. Available from: https://www.ipfcc.org/ bestpractices/covid-19/index.html

8. Wright LM, Leahey M. Enfermeiras e famílias-um guia para avaliação e intervenção na família. 5a ed. São Paulo: Editora Roca;2012. 294 p.

9. Kripka LMR, Scheller M, Bonotto DL. Pesquisa documental na pesquisa qualitativa: conceitos e caracterização. Rev Investig UNAD [Internet]. 2015 [cited 2020 Aug 15];14(2)55-73. Available from: https://core.ac.uk/download/pdf/322589335.pdf

10. Luttik MLA, Mahrer-Imhof R, García-Vivar C, Brødsgaard A, Dieperink KB, Imhof L, et al. The COVID-19 pandemic: a family affair. J Fam Nurs. 2020;26(2):87-9. https://doi.org/10.1177/1074840720920883

11. Braun V, Clarke V. Reflecting on reflexive thematic analysis. Qualit Res Sport, Exerc Health. 2019;11(4):589-97. https://doi.org/10.1080/21596 76X.2019.1628806

12. O'Brien BC, Harris IB, Beckman TJ, Reed DA, Cook DA. Standards for Reporting Qualitative Research, Acad Med. 2014;89(9):1245-51. https:// doi.org/10.1097/ACM.0000000000000388

13. AC Camargo Cancer Center. O novo coronavírus e os cuidados para o câncer infantil[Internet]. 2020[cited 2020 Apr 28]. Available from: https://www.accamargo.org.br/noticias/novo-coronavirus-e-cancer-infantil-conheca-os-cuidados-necessarios-para-os-pequenos

14. American Childhood Cancer Organization. Coronavirus guidance for young cancer patients[Internet]. 2020[cited 2020 May 05]. Available from: https://www.acco.org/coronavirus/

15. Stenger M. COVID-19 and pediatric patients with cancer. The ASCO Post [Internet]. 2020 [cited 2020 Apr 30]. Available from: https://www. ascopost.com/news/april-2020/covid-19-and-pediatric-patients-with-cancer/

16. Mancini N. Se proteja do coronavírus e dos boatos sobre ele. Rev Abrale [Internet]. 2020 [cited 2020 May 07]. Available form: https://www. abrale.org.br/revista-online/coronavirus-e-boatos-sobre-ele/

17. Australian \& New Zealand Childrens Haematology/Oncology Group. COVID-19 Guidance and FAQ for children and young people undergoing cancer treatment[Internet]. 2020[cited 2020 May 07]. Available from: https://anzchog.org/ covid-19-guidance-for-children-and-young-people-undergoing-cancer-treatment/

18. BC Children's Hospital. COVID-19 and children- information for patients[Internet]. 2020[ cited 2020 Apr 20]. Available from: https://www. cclg.org.uk/Coronavirus-advice

19. Centro Boldrini. Orientações Gerais Covid 19. Informes Covid[Internet]. 2020[cited 2020 Apr 22]. Available from: https://www.boldrini.org.br

20. Childhood Cancer Association. Our response to COVID-19 (coronavirus) [Internet]. 2020 [cited 2020 Apr 22]. Available from: https:// childhoodcancer.asn.au

21. Children with cancer. Keeping family together. Give hope to children facing cancer amid COVID-19 uncertainty: looking within during the COVID-19 crisis[Internet]. 2020[cited 2020 Apr 24]. Available from: https://www.childrenwithcancer.org.uk/how-you-can-help/ other-ways-to-give/covid-19-uncertainty/ 
22. Children's Cancer and Leukaemia Group. COVID-19 guidance for children and young people with cancer undergoing treatment[Internet]. 2020[cited 2021 Jan 05]. Available from: https://www.cclg.org.uk/Coronavirus-advice

23. Children's Oncology Group. COVID-19 and Cancer Survivors: what do i need to know? [Internet]. 2020[cited 2020 Mar 24]. Available from: http://www.survivorshipguidelines.org/pdf/2020/COVID-19_Health_Link_English.pdf

24. Cure Childhood Cancer. [EUA: Atlanta, GA]: CURE childhood cancer and COVID-19[Internet]. 2020[cited 2020 May 15]. Available from: https://curechildhoodcancer.org/cure-and-covid-19/

25. Grupo de Apoio à Criança com Câncer da Bahia. Conheça as medidas adotadas pelo GACC-BA para combater o Covid-19[Internet]. 2020[cited 2020 May 15]. Available from: http://www.gaccbahia.org.br/noticias/item/conheca-as-medidas-adotadas-pelo-gacc-ba-para-combater-o-covid-19

26. Grupo de Pesquisa e Assistência ao Câncer Infantil. O que é coronavírus? Saiba quando foi descoberto e quais medidas tomar para prevenção[Internet]. 2020[cited 2020 May 15]. Available from: https://www.gpaci.org.br/novidade/ saiba-quando-foi-descoberto-e-quais-medidas-tomar-para-prevencao-103

27. Grupo de Apoio ao Adolescente e à Criança com Câncer. Informe GRAACC Covid-19[Internet]. 2020[cited 2020 May 15]. Available from: https://graacc.org.br/2020/03/23/informe-graacc/

28. Erasto Gaertner. Plano de enfrentamento coronavirus[Internet]. 2020 [cited 2020 May 14]. Available from: https://erastogaertner.com.br/ pagina/plano-de-enfrentamento-coronavirus

29. Hospital Oncológico Infantil Octávio Lobo. As crianças que fazem parte do grupo de risco do coronavirus[Internet]. 2020 [cited 2020 May 14]. Available from: https://oncologicoinfantil.org.br/2020/04/13/as-criancas-que-fazem-parte-do-grupo-de-risco-do-coronavirus/

30. Ministério da Saúde (BR). Instituto Nacional do Câncer. INCA contra coronavirus[Internet]. [cited 2020 May 3]. Available from: https://www. inca.gov.br/noticias/inca-contra-coronavirus

31. Instituto Oncoguia. COVID-19 Coronavírus[Internet]. 2020 [cited 2020 May 14]. Available from: http://www.oncoguia.org.br/coronavirus/

32. Instituto Ronald McDonald. "COVID-19. Precisamos de você! Faça uma doação especial." [Internet]. 2020[cited 2020 Apr 20]. Available from: https://institutoronald.org.br/

33. Instituto de Tratamento ao Câncer Infantil (ITACI). Atendimento especial: COVID-19[Internet]. 2020[cited 2020 May 13]. Available from: https://www.itaci.org.br/covid-19

34. Sociedade Brasileira de Enfermeiros Pediatras (SOBEP). Recomendações da Sociedade Brasileira de Enfermeiros Pediatras em tempos de Coronavírus (COVID-19) [Internet]. 2020 [cited 2020 Apr 22]. Available from: https://sobep.org.br/conteudo/orientacao-covid-29/

35. Sociedade Brasileira de Oncologia Pediátrica (SOBOPE). Comunicado importante sobre o COVID-19[Internet]. 2020[cited 2020 May 10]. Available from: http://sobope.org.br/apex/f?p=106:LOGIN

36. Sociedade Brasileira de Pediatria. Crianças e adolescentes com câncer: cuidados especiais em tempos de coronavírus[Internet]. 2020 [cited 2020 Apr 28]. Available from: https://www.sbp.com.br/especiais/pediatria-para-familias/doencas/ criancas-e-adolescentes-com-cancer-cuidados-especiais-em-tempos-de-coronavirus/

37. St. Jude Children's Research Hospital. What does COVID-19 (Coronavirus) mean for children with cancer or other illnesses? [Internet]. 2020 [cited 2020 Apr 17]. Available from: https://together.stjude.org/en-us/care-support/covid-19.html

38. World Child Cancer. Responding to coronavirus/COVID-19[Internet]. 2020 [cited 2020 May 10]. Available from: https://www. worldchildcancer.org/responding-coronaviruscovid-19

39. Sargent Cancer Care for Children CLIC. Coronavirus guidance for young cancer patients[Internet]. 2020 [cited 2020 May 14]. Available from: https://www.clicsargent.org.uk/what-we-do/supporting-you-through-coronavirus/coronavirus-guidance-for-young-cancer-patients/

40. Bouffet E, Challinor J, Sullivan M, Biondi A, Rodriguez-Galindo C, Pritchard-Jones K. Early advice on managing children with cancer during the COVID-19 pandemic and a call for sharing experiences. Pediatr Blood Cancer. 2020;67:e28327. https://doi.org/10.1002/pbc.28327

41. Sullivan M, Bouffet E, Rodriguez-Galindo C. The COVID-19 pandemic: a rapid global response for children with cancer from SIOP, COG, SIOP-E, SIOP-PODC, IPSO, PROS, CCI, and St Jude Global. Pediatr Blood Cancer. 2020;67(7):e28409. https://doi.org/10.1002/pbc.28409

42. Schroeder WK. Leveraging social media in \#familynursing practice. J Fam Nurs. 2017;23(1):55-72. https://doi.org/10.1177/1074840716684228

43. Mooney-Doyle K, Santos MR, Woodgate RL. Family-Centered Care in Pediatric Oncology. In: Hinds P, Linder L (Eds). Pediatric Oncology Nursing. Pediatric Oncology [Internet]. 2020 [cited 2020 Jul 15]. 348 p. https://doi.org/10.1007/978-3-030-25804-7_2

44. Gonçalves RC, Tristão G, Chaves E, Moreira A, Assunção L, et al. Qualidade de páginas brasileiras da internet que disponibilizam informações sobre micoses humanas. Multi-Sci J [Internet]. 2019 [cited 2020 Aug 15];2(1):23-32. Available from: https://www.ifgoiano.edu.br/periodicos/ index.php/multiscience/article/view/633/760

45. Benedetti GMS, Higarashi IH, Sales CA. Experiences of mothers and fathers of children and adolescents with cancer: a phenomenologicalexistential Heideggerian approach. Texto Contexto enferm. 2015;24(2):554-62. https://doi.org/10.1590/0104-07072015002702014

46. Hogan S, Ross MJ, Balsamo WL, Mitchell HR, Kadan-Lottick, NS. Parental perception of child vulnerability in childhood cancer survivors. Pediatr Blood Cancer. 2018;65(11):e27364. https://doi.org/10.1002/pbc.27364

47. Dobrozsi S, Tomlinson K, Chan S, Belongia M, Herda C, Maloney K, et al. Education milestones for newly diagnosed pediatric, adolescent, and young adult cancer patients: a quality improvement initiative. J Pediatr Oncol Nurs. 2019;36(2):103-18. https://doi. org/10.1177/1043454218820906 
48. Gage-Bouchard EA, LaValley S, Mollica M, Beaupin LK. Cancer communication on social media: examining how cancer caregivers use Facebook for cancer-related communication. Cancer Nurs. 2017;40(4):332-8. https://doi.org/10.1097/NCC.0000000000000418

49. Silva LF, Cabral IE. Cancer repercussions on play in children: implications for nursing care. Texto Contexto Enferm. 2014;23(4):935-43. https:// doi.org/10.1590/0104-07072014002380013

50. Almeida CB, Lima GR. ONGs: prática cidadã ou omissão de um estado regulador? Periferia. 2019;11(1):240-59. https://doi.org/10.12957/ periferia.2019.34455 